\title{
ECONOMIC MODELS OF OPTIMAL ENTERPRISE PRODUCTION OUTPUT STRATEGY
}

\author{
M. A. Demydenko, Ph. D (Tech.), Associate Professor, Dnipro University of Technology, \\ demidenko.m.a@nmu.one.orcid.org/0000-0001-6298-2079 \\ D. V. Kabachenko, Ph. D (Econ.), Associate. Professor, Dnipro University of Technology, \\ kabachenko.d.v@nmu.one.orcid.org/0000-0001-6126-4809
}

Methods. The article explores and substantiates methods for determining consumer demand and, on this basis, develop optimal production plans considering technological, operational and market restrictions.

Results. Model of optimal strategy production output are proposed Implementation of these methods allows the company to be more competitive. The research was carried out at «Pridneprovsky» company, Dnipro, Ukraine. The company is a modern, mechanized and automated business. Nowadays the company produces more than one hundred kinds of dairy products. The company controls the terms of production, storage and transportation of their products from a farm to the sale of finished products. Economic efficiency of «Prydniprovsky» company depends on the timely and proper response to consumer demand. Therefore, the enterprise must adapt plans and range of foods. These changes may range from once a month to once in ten days. Adjustment plans, in most cases, are carried out by income criteria or sales volume. This calculation is usually performed manually, and decisions are made by experienced specialists. These decisions can be attributed to rational or close to optimal. Practice management now shows that such plans and management decisions are not perfect. Deficiencies are caused by different experience planning professionals, lack of time to consider all the factors, subjective approaches to solving the problems. The proposed methodology eliminates these shortcomings and allow to increase profitability of this enterprise.

Novelty. Proposed models and methods given differ from the existing ones by the formalized approach, the use of economic mathematical models of demand assessment and optimal finished product determination considering technological and market constraints.

Practical importance. The models of demand forecast and calculation of the optimal plan of production of the «Pridneprovsky» company are offered. Models allow to increase profitability and competitiveness of this enterprise. The results of the study presented in the article are of practical interest for businesses operating in the consumer market.

Keywords. Optimization, demand, forecast model, production output, criterion, technological constraints, correlation.

Problem statement. At present, in the current economic situation, it is necessary for the company to form an effective strategy of production. To do this, the company needs to forecast the demand for products and in accordance with this demand to formulate a production program.

Therefore, it is advisable to explore scientifically the substantiated methods for determining customer demand and on this basis to develop optimal production plans considering technological, operational and market constraints.

Analysis of recent research and publications. Commercial enterprises tasks of industrial activity planning economicmathematical models are studied and described in many research papers. So, the paper [1] presents the concept and algorithm of the complex production program development and implementation. 
Efficiency estimates of the product range management system on market are presented in paper [2]. Practical recommendations for enterprise efficiency improving are investigated and provided in the paper [3]. Production program optimization as a part of the dynamic system of the enterprise activity planning was carried out in research paper [4]. In the publication [5] the process of forming an enterprise's production program is considered and mathematical model for estimating the level of uncertainty is proposed .

Enterprise production program planning system using economic and mathematical methods and models is proposed in research paper [6]. The article [7] substantiates the necessity and expediency of the production program fuzzy linear optimization model with flexible restrictions of production resources.

Complex analysis was carried out and some methods of forming an effective goods assortment were proposed in the paper [8].

Despite many scientific publications on the chosen topic enterprise's production program formation economic-mathematical model needs further improvement.

Formulating the purpose of the article. The purpose of the article is to develop scientifically the substantiated methodology for optimal production plans considering forecast of customer demand, technological, operational and market constraints

Outline of the main research material. Investigation of demand for products is performed in two stages. The first stage includes the research and product sales analysis, the second one calculation of optimal output to meet the demands. The assortment and volume of products are calculated for each consumer who buys them. As a result, the company can identify the most profitable customers and to link production with actual market needs, improve sales system, establish an individual approach to meet the individual consumer's needs.

Every month several parameters are calculated for each consumer.

The average volume of products purchased from a consumer to an enterprise.

$$
\bar{P}_{i j}=\frac{\sum_{k=1}^{\mathrm{n}} p_{i j}{ }^{k}}{n}
$$

where $-p_{i j}$ sales $i$-product type $j-$ consumer, for $k$-day,

$$
\bar{P}_{i j} \text { - sales } i \text {-product type } j \text {-consumer }
$$

per month,

$n$ - number of days in the month.

Standard deviation in sales during the month of the average volume is estimated by the following equation:

$$
S_{i j}=\sqrt{\frac{\sum_{i=1}^{n}\left(p_{i j}{ }^{k}-P_{i j}\right)^{2}}{n-1}}
$$

In general, the rate of satisfying demand for the i-th kind of production will be calculated by the formula:

$$
K_{i}=\frac{\sum_{j=1}^{m}\left(z_{i j}{ }^{k}-\bar{P}_{i j}\right)}{\sum_{j=1}^{m} z^{k}{ }_{i j}} 100 \%
$$

where, $z_{i j}{ }^{k}$ - request for $\mathrm{i}$-th type of product, per $\mathrm{j}$ day, by $\mathrm{k}-\mathrm{s}$ customer.

The variable Ki can identify those customers and products, which do not meet the demand. Further, this value should be used to adjust the production enterprise program, raw materials purchase policy and enterprise development [12].

For quantitative assessment of demand and production of the i-th type of product in time we introduce the Ri coefficient.

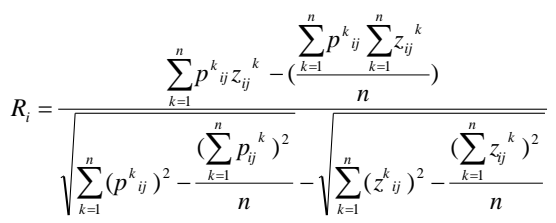

Thus, if the value $\mathrm{Ri}$ is within $0,8-1$, the production properly responds to the demand change on this product type. If $\mathrm{Ri}$ is within $0,8-$ 0,4 , the production does not meet the demand and needs to review the approach to the production. If $\mathrm{Ri}$ is less than 0.4 enterprise pays no attention to these products.

The next stage assesses the consumers tastes around the city of Dnipro. The analysis shows the products which are in demand in the given area of the city to provide product plan- 
ning taking into account the benefits of different social groups living in the area.

For this purpose, consumers of the regions are grouped and supply and demand for the kinds of products $Z_{i j}{ }^{m}, P^{m}{ }_{i j}$ are counted up, where $m$ - number of the area of town. Then goods that meet the highest demand are calculated by the formula $Z_{\max }=\underset{i-1 . m}{\max \left(Z_{i j}^{m}\right)}$. Then the coefficient of demand is calculated.

$$
K^{*}=\frac{Z_{\max }-P_{\max }}{Z_{\max }} 100 \%
$$

where $\boldsymbol{P}_{\max }$ - products which meet the highest demand.

The analysis of $\mathrm{K} *$ coefficients makes it possible to adjust production for the most important consumer products[12],[9].

In order to timely meet the demand for products short-term forecasting models are proposed [7],[8],[9]. The models make it possible to calculate the demand for the next planning period [10],[11]. Forecasting results are given to the enterprise administration for production program adjustment.

Model of Short-term Forecasting of Demand for Products. In order to forecast the processes with rather high sales (more than 100 outlets), there is a convenient forecast approach using Fourier transformation with a further ranging trend separation[13].

Let $x(t)$ is a random process specified by $\mathrm{x}_{\mathrm{i}}, \mathrm{i}=1$.. $\mathrm{n}$. Having expanded this process in Fourier serial by means of fast Fourier transformation, then we get the following:

$$
c_{j}=\frac{1}{\sqrt{n}} \sum_{k=0}^{n-1} x_{k} e^{2 \pi i(j / n) k}
$$

where $\mathrm{n}-$ number of values in the sample $\mathrm{X}_{\mathrm{i}}$

$c_{j}-$ Fourier serial expansion coefficient.

We calculate the absolute value, $\mathrm{j}=1$, $\ldots, \mathrm{m}$ and calculate the trend frequency using the formula:

$$
g_{j}=c_{j} \cdot H\left(\left|c_{j}\right|-L\right)
$$

where

$$
\mathrm{H}(\mathrm{x})=\left\{\begin{array}{lll}
1 & \text { if } & \mathrm{x}>=0 \\
0 & \text { if } & \mathrm{x}<0
\end{array}\right.
$$

With (7), the coefficients in the expansion, which values are lower of the threshold $\mathrm{L}$ are converted to zero. Thus, the random component in the spectrum is truncated. The remaining coefficients describe the trend. Having applied the inverse Fourier transformation to $\mathrm{c}_{\mathrm{j}}$, trend value is restored. Continuing the obtained trend for 1-5 values forward, we produce forecast with low relative error.

It is suggested to apply the extrapolation formulae that use one and two prehistory points.

For one-point extrapolation, the formula is of the form:

$$
x_{t+1}=\frac{K_{x}(t)}{K_{x}(0)}\left(x_{t}-\bar{x}\right)+\bar{x},
$$

where $\boldsymbol{x}_{t+1}$ - estimated value, $x_{t}-$ prehistory point.

$$
\bar{x}=\frac{\sum_{i=1}^{n} x_{i}}{n}
$$

$\mathrm{Kx}(1), \mathrm{Kx}(2)$ - values of the correlation functions for $\tau=1$ and $\tau=2$. formula:

Correlation function is calculated by the

$$
K_{x}(\tau)=\frac{1}{(n-\tau)} \sum_{i=1}^{n-\tau}\left(x_{i}-\bar{x}\right)\left(x_{i+\tau}-\overline{(10}\right)
$$

To forecast two prehistory points, the extrapolation formula is of the form:

$$
x_{t+1}=\frac{K_{x}(0) K_{x}(1)-K_{x}(2) K_{x}(1)}{K_{x}^{2}(0)-K_{x}^{2}(1)} x_{t}+\frac{K_{x}(0) K_{x}(2)-K_{x}^{2}(1)}{K_{x}^{2}(0)-K_{x}^{2}(1)} x_{t-1}-\left[\frac{K_{x}(1)-K_{x}(2)}{K_{x}(0)-K_{x}(1)}-1\right]
$$

The maximum mean quadratic error for the formula (8) will be equal:

$$
\varepsilon_{1}^{2}=K_{x}(\mathrm{O})-\frac{K_{x}^{2}(1)}{K_{x}(\mathrm{O})}
$$

The maximum mean quadratic error for the formula (11) will be equal:

$$
\varepsilon^{2}=K_{x}(0)-\frac{K_{x}(0) K_{x}^{2}(1)-2 \cdot K_{x}^{2}(1) K_{x}(2)+K_{x}(0) K_{x}^{2}(2)}{K_{x}^{2}(0)-K_{x}^{2}(1)}
$$


The forecast results analysis by one and two prehistory points has shown that the prediction accuracy is slightly higher at an extrapolation of two prehistory points, although the accuracy increase is negligible. The value of correlation function $\operatorname{Rx}(\tau)$ for $\tau=1,2$ must satisfy the inequality:

$$
\begin{aligned}
& R_{x}(1)=\frac{K_{x}(1)}{K_{x}(0)}>0,4 \div 0,5 \\
& R_{x}(2)=\frac{K_{x}(2)}{K_{x}(0)}>0,4 \div 0,5
\end{aligned}
$$

The average quadratic prediction error for one prehistory point for $\operatorname{Rx}(1)>=0,4$ will be equal to $\varepsilon^{2}=0,84 \cdot K_{x}(0)$.

To forecast errors for two prehistory points for $\operatorname{Rx}(1)>=0,5$ and $\operatorname{Rx}(2)>=0,4$ we will get:

$$
\varepsilon^{2} \leq \frac{0,79 \cdot K_{x}^{3}(0)-0,5 \cdot K_{x}^{2}(0)}{K_{x}^{2}(0)-0,5 \cdot K_{x}(0)}
$$

The formulae given demonstrate that these models make it possible to describe and predict the processes that satisfy the given constraints.

To determine the optimal strategy of products, the economic and mathematical mod$\mathrm{el}$ is proposed. The criterion of optimization is the minimum costs of production, inventory, fulfillment of basic and overtime operations.

$$
\begin{aligned}
\sum_{i=1}^{N} \sum_{t=1}^{T}\left(v_{i t} x_{i t}+c_{i t} I_{i t}{ }^{+}+b_{i t} I_{i t}{ }^{-}\right)+\sum_{t=}^{T}\left(r_{t} w_{t}+a_{t} O_{t}+h_{t} H_{t}+f_{t} F_{t}\right) \rightarrow \min \\
\left\{\begin{array}{l}
x_{i t}+I^{+}{ }_{i, t-1}-I^{-}{ }_{i, t-1}=z^{t} ;(17) \\
\sum_{i=1}^{N} k_{i} x_{i t}-w_{t}-O_{t} \leq 0 ;(18) \\
w_{t}-w_{t-1}-H_{t}+F_{t}=0 ;(19) \\
-p_{t} w_{t}+O_{t} \leq 0 ;(20)
\end{array}\right.
\end{aligned}
$$$$
x_{i t} \geq 0 \text {; }
$$$$
I_{i t}^{+} \geq 0 \text {; }
$$$$
I_{\text {it }}{ }^{-} \geq 0 \text {; }
$$$$
w_{t}, O_{t}, P_{t}, H_{t}, F_{t} \geq 0
$$$$
i=1,2 \ldots N ; j=1,2 \ldots T \text {. }
$$$$
x_{i t} \text { - production output within the } \mathrm{t} \text { peri- }
$$
od;

$v_{i t}$ - unit cost produced within the $\mathrm{t}$ period; $c_{i t}$ - storage costs per unit of i-type products of $\mathrm{t}$ period;

$$
\mathrm{I}_{i t}^{+}-\text {volume of product stored during pe- }
$$
riod $\mathrm{t}$;

$I_{i t}{ }^{-}-$volume of product, which was not supplied to the consumer for the t period;

$b_{i t}-$ losses due to the lack of i-product;

$r_{i t}$ - the cost of man-hour of primary labour force for the t period;

$w_{t}$ - number of man-hour of primary labour force necessary for production output during the $\mathrm{t}$ period;

$$
a_{t}-\text { man-hour cost of overtime labour }
$$
force during the t period;

$O_{t}$ - number of man-hours of overtime labour force needed for production during the $t$ period;

$h_{t}$ - man-hour cost of additionally employed labour force during the t period;

$H_{t}$ - number of man-hours of additionally employed labour force needed for production during the t period;

$f_{t}$ - man -hour cost of fired labour force during the t period;

$F_{t}$ - number of man-hours of fired labour force during the $\mathrm{t}$ period;

$\mathrm{N}$ - number of products varieties;

$\mathrm{T}$ - number of planning periods of $\mathrm{t}$ length each;

$z_{i}-$ demand for i product during the t period;

$k_{i}-$ unit labour costs for production of the i-th product;

$P_{t}$ - percentage of overtime work during the $\mathrm{t}$ period.

Restriction (17) balances demand, production, stocks and debt on goods. Restriction (18) is imposed on the available workforce. Equation (19) limits the changes in workload and labor. Restriction (20) is imposed on the upper limit of the use of overtime work.

Conclusions. The method of the demand calculation of the company products that makes it possible to determine the amount of demand as well as properly respond to changes of consumer preferences and quantify the response quality on changing demand is proposed. 
The economic and mathematical model proposed enables to determine the optimal amount of production considering technological, operational, and market constraints, the model is implemented on the PC using the improved simplex method.

Calculation results are provided to the company executives to make the final management decisions.

The economic and mathematical models can significantly reduce the undermade profits and improve the whole enterprise efficiency.

\section{Література}

1. Чорна Л. О. Виробнича програма. Проблеми організації / Л. О. Чорна, О. М. Чумак, Н. Ю. Чорна // Ефективна економіка: електронне наукове фахове видання. - 2010. - №10. [Електронний ресурс]. - Режим доступу: http: // www.economy.nayka.com.ua/?op=1\&z=375

2. Біленький О. Ю. Удосконалення системи управління сортуванням продукції: напрямки та ефективність / О. Ю. Біленький // Вісник ОНУ імені I.I. Мечников. - 2013. - Том 18. - № 1/1, С. 31-37.

3. Гайдаєнко О. Аналіз беззбитковості підприємства на прикладі «Дніпропетровської пекарні №9» / О. Гайдаєнко, Т. Кушнір // Бухгалтерська економіка управління: наукові записки: міжнародний збірник наукових праць Луцького НТУ. - 2016. - № 1 (9). Частина 1, С. 72-78.

4. Падерін І. Д. Виробнича програма як основа динамічної системи планування промислових підприємств / І. Д. Падерін // Журнал АМСУ. Серія «Економіка». - 2015. - № 1 (53). - С. 135-142.

5. Повідайчік М. М. Особливості стратегічного планування виробничої програми легкої промисловості в призових умовах в умовах невизначеності / М. М. Повідайчік // Науковий вісник Ужгородського унту. Серія «Економіка». - 2014. - №. 1(42). - С. 59-63.

6. Фесшур Р. В. Маркетингове планування виробничої програми фірмового бізнесу / Р. В. Фесшур, О. Б. Свірська // Теоретичні та прикладні питання економіки: збірник наукових праць Київського національного університету. - 2010. - №. 23. - С. 112121.

7. Карпенко I. I. Оптимізація виробничої програми підприємства через незрозумілі обмеження / I. I. Карпенко // Управління розвитком складних систем: збірник наукових праць Київського національного університету будівництва та архітектури. 2014. - № 20. - С. 170-173.

8. Демиденко М. Системи планування ресурсів підприємства / М. Демиденко. - Saarbrucken, Deutschland: LAMBERT Academic Publishing, 2019. $142 \mathrm{c}$.

9. Демиденко М. А. Економіко-математична модель оптимального ціноутворення постачальників і переробників сировини для сталого розвитку гірничо-металургійного комплексу України / М. А. Демиденко. // International Scientific Conference Anti-Crisis Management: State, Region, Enterprise: Conference
Proceedings, Part III, Le Mans, France: Baltic States. 2017. - №1. - P. 141-142.

10. Демиденко М. А. Економіко-математична модель - оптимізація маркетингових компаній у пошукових системах. / М. А. Демиденко, О. Ю. Чуриканова. // «Intelekt XXI». - Випуск 2. - 2019. - С. 2730.

11. Чуріканова О. Ю. Моделі підтримки прийняття рошених при торгівлі крипто валютою. / О. Ю. Чуріканова, Ь. А. Демиденко // Вісник ХНУ. - 2019. №2. - Хмельницький. - 2019. - С. 89-103. DOI: 10.31891 / 2307-5740-2019-268-2-114-118

12. Демиденко М. Метод вибору ERP-систем за допомогою моделей багатокритеріальної оптимізації / М. А. Демиденко // Науковий Вісник НГУ. 2018. - №5. - C. 132-137. DOI: 10/29202 / nvngu / 2018-5 / 21

13. Демиденко М. А. Оптимізація функціонування українського біонезу на національному та зовнішньому ринках в умовах ускладнення постачання сировини. Соціальна відповідальність влади, бізнесу, городян: за ред. Г. Г. Півняка; М-во освіти і науки України; Нац. гірн. ун-т. - Д. : НГУ, 2014. - С. 115126.

14. Кабаченко Д. В. Прийняття управлінських рішень в умовах невизначеності та ризику / Д. В. Кабаченко // Економічний вісник НГУ. - 2017. - №2 (58). C. $107-115$.

15. Кабаченко Д. В. Вибір в реалізації стратегії управлінського персоналу підприємства / Д. В. Кабаченко, А. В. Луценко // Науковий вісник Херсонського державного університету. Серія: Економічні науки. - Херсон : Херсонський державний університет, Видавний дім «Гельветика». - 2015. - Вип. 15. Ч.. 1. - С. $58-62$.

\section{References}

1. Chorna, L.O., Chumak, O.M., \& Chorna, N.Yu. (2010). Vyrobnycha programa. Problemy organizatsii. Efectivna economika: electronnne naukove fakhove vydannia, (10). Received from http: // www.economy.nayka.com.ua/ op $=1 \& z=375$

2. Bilenkyi, O.Yu. (2013). Udoskonalennia systemy upravlinnia sortuvanniam produktsii: napriamky ta efektyvnist. Visnyk ONU imeni I.I. Mechnikova. Volume 18, 1/1, 31-37.

3. Haydaienko, O., Kushnir, T. (2016). Analiz bezzbytkovosti pidpryiemstva na prykladi «Dnipropetrovskoi pekarni №9». Bukhhalterska ekonomika upravlinnia: naukovi zapysky: mizhnarodnyy zbirnyk naukovykh prats Lutskoho NTU, № 1 (9). Part 1, 72-78.

4. Paderin, I.D. (2015). Vyrobnycha prohrama yak osnova dynamichnoi systemy planuvannia promyslovykh pidpryiemstv. Zhurnal AMSU. Seriya «Ekonomika», 1 (53), 135-142.

5. Povidaychyk, M.M. (2014). Osoblyvosti stratehichnoho planuvannia vyrobnychoi prohramy lehkoi promyslovosti $\mathrm{v}$ pryzovykh umovakh $\mathrm{v}$ umovakh nevyznachenosti. Naukovyy visnyk Uzhhorodskoho universytetu. Seriia «Ekonomika», 1(42), 59-63.

6. Feschur, R.V., \& Svirska, O.B. (2010). Marketynhove planuvannia vyrobnychoi prohramy 
firmovoho biznesu. Teoretychni ta prykladni pytannia ekonomiky: zbirnyk naukovykh prats Kyivskoho natsionalnoho universytetu, (23), 112-121.

7. Karpenko, I.I. (2014). Optymizatsiia vyrobntchoi prohramy pidpryiemstva cherez nezrozumili obmezhennia. Upravlinnia rozvytkom skladnykh system: Zbirnyk naukovykh prats Kyivskoho natsijnalnoho universytetu budivnytstva ta arkhitektury, (20), 170-173.

8. Demydenko, M. (2019). Enterprise resource planning systems. Saarbrucken, Deutschland: LAMBERT Academic Publishing, 142 p.

9. Demydenko, M.A. (2017). Economic and mathematical model of optimal pricing of suppliers and processors of raw materials for sustainable development of the mining and metallurgical complex of Ukraine. Proceedigs from: MIIM' International Scientific Conference Anti-Crisis Management: State, Region, Enterprise», Part III, Le Mans, France: Baltic States. (1), 141142.

10. Demydenko, M.A., Churikanova O.Yu. (2019). Ekonomiko-matematychna model optymizatsiyi marketynhovykh kompaniy $\mathrm{v}$ poshukovykh systemakh. «Intelekt XXI», vypusk (2), 27-30.
11. Churikanova, O.Yu. \& Demydenko, M.A. (2019). Modeli pidtrymky pryynyattya rishen pry torhivli krypto valyutoyu. Visnyk KHNU, (2), 89-103. Khmelnytskyy. DOI: 10.31891/2307-5740-2019-268-2-114-118.

12. Demidenko, M. (2018). Metod vyboru ERPsystem za dopomohoiu modeley bahatokryterialnoi optymizatsii. Naukovyi Visnyk NHU, (5), 132-137. DOI: 10/29202/nvngu/2018-5/21.

13. Demydenko, M.A. (2014). Optymizatsiya funktsionuvannya ukrainskoho biznesu na natsionalnomu ta zovnishniomu rynkakh $\mathrm{v}$ umovakh uskladnennya postachannya syrovyny. Sotsialna vidpovidalnist vlady, biznesu, horomadian. T.1. H.H. Pivnyak (Ed). Dipropetrovsk: NHU.

14. Kabachenko, D.V. Pryynyattia upravlinskykh rishen $\mathrm{V}$ umovakh nevyznachenosti ta ryzyku. Ekonomichnyy visnyk Natsionalnoho Hirnychoho Universytetu, 2 (58), 107-115.

15. Kabachenko, D.V., \& Lutsenko, A.V. (2015). Vybir $\mathrm{v}$ realyzatsii stratehii upravlinskoho personalu pidpryiemstva. Naukovyy visnyk Khersonskoho derzhavnoho universytetu. Seriya: Ekonomichni nauky, Vyp. 15, Ch. 1, 58-62. Kherson: Khersons'kyy derzhavnyy universytet, Vydavnychyy dim «Helvetyka».

\section{ЕКОНОМІКО-МАТЕМАТИЧНІ МОДЕЛІ ОПТИМАЛЬНОЇ ВИРОБНИЧОЇ СТРАТЕГІЇ М. А. Демиденко, к. т. н., доиент, НТУ«Дніпровська політехніка» Д. В. Кабаченко, к. е. н., дочент. НТУ«Дніпровська політехніка»}

Методологія дослідження. У статті досліджуються та обгрунтовуються методи прогнозування споживчого попиту які використовуються для моделі розрахунку оптимального плану виробництва готової продукції з урахуванням технологічних, експлуатаційних та ринкових обмежень.

Результати. Запропоновано моделі розрахунку оптимального обсягу виробництва продукції. Впровадження цих моделей дозволяє компанії бути більш конкурентоспроможною. Дослідження проводилось у комбінаті «Придніпровський», м. Дніпро, Україна. Компанія - це сучасний, механізований та автоматизований бізнес. На сьогоднішній день компанія виробляє більше ста видів молочної продукції. Компанія контролює умови виробництва, зберігання та транспортування своєї продукції з ферми до продажу готової продукції. Економічна ефективність комбінату «Придніпровський» залежить від своєчасного та правильного реагування на попит споживачів. Тому підприємство повинно адаптувати плани та асортимент продуктів. Ці зміни планів впроваджують від одного разу на місяць до одного разу на десять днів. Плани коригування в більшості випадків здійснюються за критеріями доходу або обсягом продажів. Розрахунки, зазвичай, виконується вручну. Практика управління показує, що такі плани та управлінські рішення є недосконалими. Недоліки зумовлені браком досвіду, часу на розгляд усіх факторів та помилками фахівців з планування. Запропонована методологія усуває ці недоліки і дозволяє запровадити науково-обгрунтовані методи і моделі для пошуку оптимальних рішень та за рахунок цього підвищити прибутковість цього підприємства.

Новизна. Запропоновані моделі та методи відрізняються від існуючих за формалізованим науково обгрунтованим підходом, використанням економічних математичних моделей оцінки попиту та дозволяють розрахувати оптимальний план випуску готової продукції 3 урахуванням технологічних та ринкових обмежень.

Практична значущість. Запропоновано моделі прогнозування попиту та розрахунку оптимального плану виробництва комбінату «Придніпровський». Моделі дозволяють підвищити прибутковість та конкурентоспроможність цього підприємства. Представлені в статті 
результати дослідження представляють практичний інтерес для підприємств, що працюють на споживчому ринку.

Ключові слова. Оптимізація, попит, прогнозна модель, виробництво продукції, критерій, технологічні обмеження, кореляція.

\section{ЭКОНОМИКО-МАТЕМАТИЧЕСКИЕ МОДЕЛИ ОПТИМАЛЬНОЙ ПРОИЗВОДСТВЕННОЙ СТРАТЕГИИ \\ М. А. Демиденко, к. т. н., доцент, НТУ «Днепровская политехника» \\ Д. В. Кабаченко, к. э. н., дочент, НТУ «Днепровская политехника»}

Методология исследования. В статье исследуются и обосновываются методы прогнозирования потребительского спроса используемых для модели расчета оптимального плана производства готовой продукции с учетом технологических, эксплуатационных и рыночных ограничений.

Результаты. Предложены модели расчета оптимального объема производства продукции. Внедрение этих моделей повышает конкурентоспособность предприятия. Исследование проводилось в комбинате «Приднепровский», г. Днепр, Украина. Комбинат - это современный, механизированный и автоматизированный бизнес. На сегодняшний день компания производит более ста видов молочной продукции. Компания контролирует условия производства, хранения и транспортировки продукции с фермы до продажи готовой продукции. Экономическая эффективность комбината «Приднепровский» зависит от своевременного и правильного реагирования на спрос потребителей. Поэтому предприятие должно адаптировать планы и ассортимент продуктов. Эти изменения планов внедряют от одного раза в месяц до одного раза в десять дней. Планы корректировки в большинстве случаев осуществляются по критериям дохода или объемом продаж. Расчеты обычно выполняется вручную. Практика управления показывает, что такие планы и управленческие решения являются несовершенными. Недостатки обусловлены нехваткой опыта, недостатком времени на рассмотрение всех факторов и ошибками специалистов по планированию. Предложенная методология устраняет эти недостатки и позволяет ввести научно обоснованные методы и модели для поиска оптимальных решений и за счет этого повысить доходность этого предприятия.

Новизна. Предложенные модели и методы отличаются от существующих в формализованным научно обоснованным подходом, использованием экономических математических моделей оценки спроса и позволяют рассчитать оптимальный план выпуска готовой продукции с учетом технологических и рыночных ограничений.

Практическая значимость. Предложены модели прогнозирования спроса и расчета оптимального плана производства комбината «Приднепровский». Модели позволяют повысить прибыльность и конкурентоспособность этого предприятия. Представленные в статье результаты исследования представляют практический интерес для предприятий, работающих на потребительском рынке.

Ключевые слова. Оптимизация, спрос, прогнозная модель, производство продукции, критерий, технологические ограничения, корреляция.

Надійшла до редакції 03.02.20 p. 